\title{
Spatial and temporal variation in denitrification and in the denitrifier community in a boreal lake
}

\author{
Antti Juhani Rissanen ${ }^{1,2, *}$, Marja Tiirola ${ }^{1}$, Anne Ojala ${ }^{3}$ \\ ${ }^{1}$ Department of Biological and Environmental Science, University of Jyväskylä, Survontie 9, 40500 Jyväskylä, Finland \\ ${ }^{2}$ Lammi Biological Station, University of Helsinki, Pääjärventie 320, 16900 Lammi, Finland \\ ${ }^{3}$ Department of Environmental Sciences, University of Helsinki, Niemenkatu 73, 15140 Lahti, Finland
}

\begin{abstract}
We investigated the spatial and temporal variation in denitrification rates (isotopepairing technique, IPT) and in the denitrifier community (examination of gene nirK by denaturinggradient gel electrophoresis [DGGE] of microbial DNA) in the sediments of a boreal, clear-water, eutrophic lake using samples collected from shallow littoral, deep littoral and shallow profundal sediments during early summer, mid-summer, autumn and winter. The measured denitrification rates (44 to $613 \mu \mathrm{mol} \mathrm{N} \mathrm{m}{ }^{-2} \mathrm{~d}^{-1}$ ) are among the lowest ever reported from lacustrine sediments. Denitrification rates varied both spatially and temporally, being highest in the profundal zone during midsummer and in the littoral zones during winter. Correlation analyses indicated that these variations were due to variations in the concentrations of nitrate and oxygen in the water overlying the sediment. The structure of the denitrifier community was temporally extremely stable and differed only slightly between the sites. Distance-based linear model (DISTLM) analysis indicated that the observed variation was probably due mainly to variations in the content of organic matter, and in the porosity, of the sediment. The structure of the denitrifier community and the denitrifying activities were uncoupled.
\end{abstract}

KEY WORDS: Denitrification $\cdot$ Lake $\cdot$ Sediment $\cdot$ nirK $\cdot$ Bacterial diversity $\cdot$ Boreal

\section{INTRODUCTION}

Denitrification is the primary mechanism by which nitrogen is removed from lakes (Saunders \& Kalff 2001a). It is an important process in the control of eutrophication as it converts fixed nitrogen compounds to gaseous forms, mostly to $\mathrm{N}_{2}$ (Fig. 1), which are biologically unavailable for most primary producers (Seitzinger 1988). It is an anaerobic process in which facultatively anaerobic microbes use nitrogen oxides as alternative terminal electron acceptors during the oxidation of organic matter (heterotrophic denitrification) or inorganic matter (autotrophic denitrification) (Zumft 1997). Usually it takes place within a very narrow anoxic zone (thickness $<10 \mathrm{~mm}$ ), immediately below the oxic-anoxic interface in sediment, where the process is being fed both by nitrate diffusing to the anoxic zone from the overlying water and by nitrate produced in the thin oxic surface zone (thickness 0.1 to $5.0 \mathrm{~mm}$ ) by nitrification (coupled nitrification-denitrification) (e.g. Seitzinger 1988, Nielsen 1992) (Fig. 1). An- other potential $\mathrm{N}_{2}$ gas forming microbial process is the anaerobic oxidation of ammonium (anammox), which is estimated to produce half of the gaseous $\mathrm{N}_{2}$ in marine ecosystems (Dalsgaard et al. 2005). However, in freshwater ecosystems anammox has so far been detected only in sediments of non-saline parts of estuaries (Dale et al. 2009, Koop-Jakobsen \& Giblin 2009) and in the anoxic water column of Lake Tanganyika (Schubert et al. 2006) and Lake Rassnitzer (Hamersley et al. 2009), and its wider importance in lacustrine nitrogen cycling remains to be studied.

Sediment denitrification has been studied during recent decades in a wide variety of different lake ecosystems (reviewed by Seitzinger 1988, Saunders \& Kalff 2001b, Steingruber et al. 2001). Studies have traditionally focused on temperate lakes, leaving the large number of lakes in the northern boreal zone almost totally unstudied. However, small lakes $\left(<50 \mathrm{~km}^{2}\right)$, which are typical of the boreal zone, are globally very important sinks of nitrogen (Harrison et al. 2009). For instance, in Finland there are 190000 


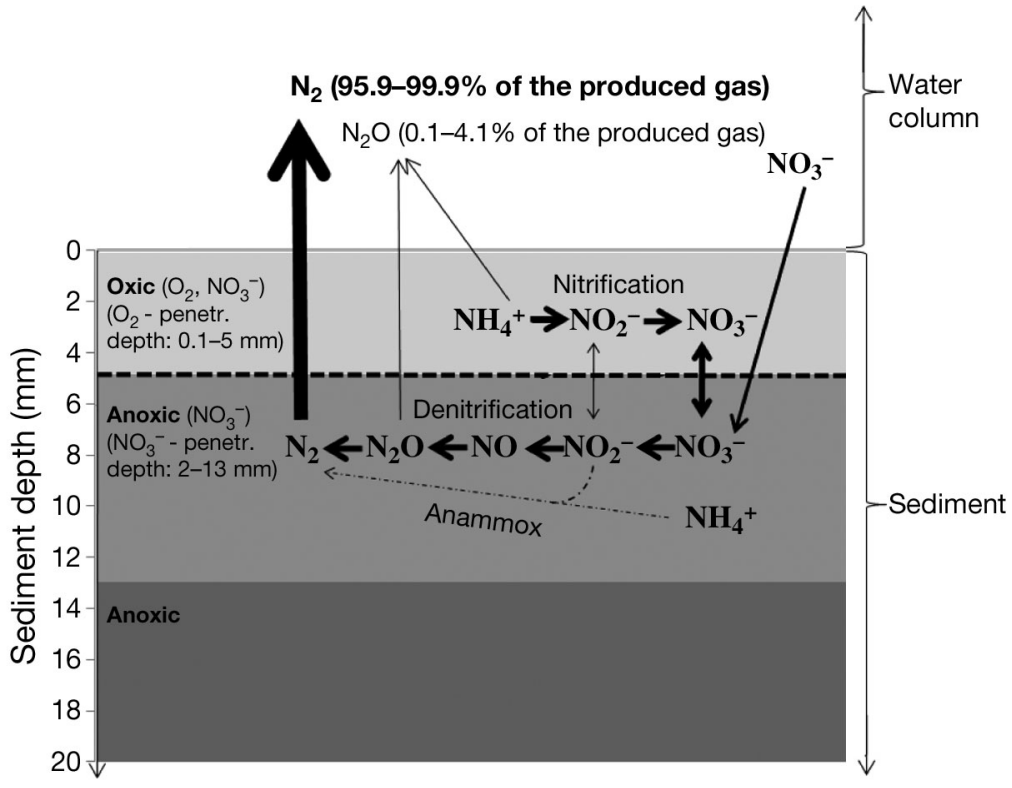

Fig. 1. Schematic representation of the vertical stratification of sediment, location of sediment nitrogen transformation processes, and percentages of $\mathrm{N}_{2}$ and $\mathrm{N}_{2} \mathrm{O}$ of the nitrogenous gas produced in the sediment. The thickness of the oxic and anoxic nitrate-containing zones is presented as the maximum values reported in previous studies on lake and river sediments (RisgaardPetersen et al. 1994, Revsbech et al. 2005, Maerki et al. 2009, Bryant et al. 2010, Hobbs et al. 2010). The range in reported oxygen and nitrate penetration depths is indicated in the figure. The percentages of $\mathrm{N}_{2}$ and $\mathrm{N}_{2} \mathrm{O}$ of the nitrogenous gas produced in the sediment are indicated as the range of reported values in previous studies on lake and river sediments (Seitzinger 1988, Svensson 1998, Silvennoinen et al. 2008)

lakes, most of them $<50 \mathrm{~km}^{2}$ (Simola \& Arvola 2005), and there have been no previous studies addressing denitrification rates in these lakes. Therefore, for future local and global nitrogen modelling, more information is needed about the mechanisms of nitrogen retention, and especially about denitrification, in these lakes. It will be important to assess both the spatial and temporal variation in denitrification rates and to recognize the factors, e.g. temperature, $\mathrm{O}_{2}$ concentration and supply of nitrate and labile organic matter (Christensen \& Sørensen 1986, Seitzinger 1988, Saunders \& Kalff 2001b), affecting this variation.

Besides environmental factors, the structure of the denitrifier community can affect process rates (e.g. Rich et al. 2003, Magalhães et al. 2008), but this has never been assessed in denitrification studies of lake sediments. Denitrifier communities are studied mostly by characterization of the diversity of functional genes coding for different reductase enzymes acting in the different steps of the nitrate reduction chain (Fig. 1) (Wallenstein et al. 2006). Reduction of nitrite is the key step in denitrification as it produces the first gaseous product (NO), which is not usable by primary producers. Therefore, the focus in studies of denitrifier communities has often been on nitrite reductase genes,
nirK and nirS (Wallenstein et al. 2006). Approaches to microbial community fingerprinting, i.e. denaturing-gradient gel electrophoresis (DGGE) (Muyzer et al. 1993, Throbäck et al. 2004) and terminal restriction fragment length polymorphism (TRFLP) (Liu et al. 1997, Rich et al. 2003), provide cost-effective but sensitive methods for performing a statistically sufficient number of replicate analyses of community structure variations (Prosser 2010). DGGE, in particular, has been shown to have good resolution of denitrifier community structure (Enwall \& Hallin 2009); indeed, the examination of nirK by DGGE has been successfully used in studies of denitrifier communities in different environments, including estuarine sediments (Fortunato et al. 2009), soils (Wertz et al. 2009) and waste-water treatment plants (Hallin et al. 2006). Overall, the emphasis in molecular ecological studies has been mostly on denitrifier communities in soils (Rich et al. 2003, Rich \& Myrold 2004, Wolsing \& Priemé 2004, Enwall et al. 2005, Rösch \& Bothe 2005) and in estuarine sediments (Nogales et al. 2002, Smith et al. 2007, Magalhães et al. 2008) and marine sediments (Braker et al. 2001, Liu et al. 2003, Tiquia et al. 2006), with very little attention paid to freshwater communities (Perryman et al. 2008), especially those in lacustrine sediments (Kim et al. 2011).

Our purpose was to evaluate the spatial and temporal variation in denitrification rates, and in the denitrifier community, in the sediments of a boreal clearwater lake. Because previous studies have indicated that shallow areas in lakes act as 'hotspots' of denitrification (Ahlgren et al. 1994, Saunders \& Kalff 2001b), the present study focused specifically on littoral and shallow profundal sites. Denitrification rates were measured by the isotope-pairing technique (IPT) (Nielsen 1992), and denitrifying communities were characterized using DGGE in nirK-based studies of microbial DNA extracted from sediments.

\section{MATERIALS AND METHODS}

Study lake. Lake Ormajärvi is a dimictic, clear-water and eutrophic lake (area: $6.5 \mathrm{~km}^{2}$; drainage area: $116 \mathrm{~km}^{2}$; maximum depth: $30 \mathrm{~m}$; mean depth: $10 \mathrm{~m}$ ) located in southern Finland $\left(61^{\circ} 06^{\prime} \mathrm{N}, 24^{\circ} 58^{\prime} \mathrm{E}\right.$ ) (see Ojala et al. 2011 for a detailed description of the study lake). The primary production in Lake Ormajärvi is strongly phosphorus-limited for most of the 
year (Ojala et al. 2011), although positive nitrogen fixation rates measured from mid-summer cyanobacterial bloom samples (Jäntti 2007) imply occasional nitrogenlimitation.

Sample collection. The lake sediments were sampled 3 times during the growing season of 2006, and once in the winter of 2007, from a transect of 3 points extending from the immediate vicinity of the littoral Typha latifolia (L.) stands to the shallow profundal zone (transect length $\sim 500 \mathrm{~m}$ ) (Table 1). Four sediment cores (sediment and overlying water) of diameter of $7 \mathrm{~cm}$ (3 field replicate cores for the denitrification incubations and 1 for background information) were collected on each occasion from each site, using plexiglass tubes connected to a gravity corer. Immediately after sampling, the tubes were sealed with rubber stoppers at both ends, covered with black plastic, placed in a cool box in an upright position, and carefully transported to the laboratory for processing, which took place within $1 \mathrm{~h}$ from sampling.

Concurrent with the sediment coring, profiles of oxygen concentrations, oxygen saturation, temperature and $\mathrm{pH}$ were measured from the whole water column above the sediment using a portable field meter (YSI 556 MPS, Yellow Springs Instruments). These measurements started $\sim 10 \mathrm{~cm}$ above the sediment surface. $\mathrm{pH}$ was not recorded at the shallowest littoral point in early summer. Other background information gathered included concentrations of dissolved inorganic nutrients $\left(\left[\mathrm{NO}_{3}{ }^{-}+\mathrm{NO}_{2}^{-}\right],\left[\mathrm{NH}_{4}{ }^{+}\right],\left[\mathrm{PO}_{4}{ }^{3-}\right]\right)$ in the water overlying the sediment (2 to $3 \mathrm{~cm}$ from the sediment surface) as well as the organic content and the porosity of the sediment. Nutrients were determined from water samples filtered through pre-rinsed filters (Millipore) of pore size $0.2 \mu \mathrm{m}$. Inorganic phosphorus (Murphy \& Riley 1962) and nitrate-nitrite (Wood et al. 1967) were determined with flow injection analysis using standard methods (QuikChem ${ }^{\circledR} 8000$, Zellweger Analytics). The organic content of the sediment (loss on ignition, LOI) was determined as the ratio of the loss of mass of the sediment after combustion at high temperature $\left(450^{\circ} \mathrm{C}\right.$ for $\left.4 \mathrm{~h}\right)$ to the dry mass of the sediment (determined by drying at $60^{\circ} \mathrm{C}$ for $48 \mathrm{~h}$ ). Sediment porosity was calculated according to Tuominen et al. (1998).

Denitrification measurements. Denitrification was assayed in the laboratory using IPT (Nielsen 1992) and following the procedures of Tuominen et al. (1998) and Hietanen (2007) who studied denitrification and anammox in the brackish Gulf of Finland. Three subsamples were taken using small plastic tubes (length $16 \mathrm{~cm}$, diameter $2.6 \mathrm{~cm}$ ) from each of the 3 field replicate cores taken on one occasion. The tubes were pushed into the sediment so that about 4 to $7 \mathrm{~cm}$ of the tube length was filled with sediment and the rest with overlying water. Oxygen and nitrate penetration depths were not measured, but according to the experience in previous studies (e.g. Revsbech et al. 2005), the sediment height

Table 1. Sampling sites, dates/seasons, number of sediment cores collected for denitrification analyses, sediment characteristics and physicochemical properties of water overlying the sediment in Lake Ormajärvi. The autumn values of sediment characteristics and physicochemical properties of littoral $(1 \mathrm{~m})$ and profundal $(8 \mathrm{~m})$ sites sampled on 2 occasions are represented as weighted averages (weighted by the number of sediment cores taken on each occasion). LOI $=$ loss on ignition, i.e. content of organic matter in sediment (\% of dry mass). $\left[\mathrm{NO}_{3}{ }^{-}\right],\left[\mathrm{NH}_{4}{ }^{+}\right],\left[\mathrm{PO}_{4}{ }^{3-}\right],\left[\mathrm{O}_{2}\right], \mathrm{O}_{2}$ sat., $\mathrm{T}$ and $\mathrm{pH}=$ concentrations of nitrate, ammonium, phosphate and oxygen; oxygen saturation, temperature and $\mathrm{pH}$ of the water overlying the sediment, respectively

\begin{tabular}{|c|c|c|c|c|c|c|c|c|c|c|c|}
\hline $\begin{array}{l}\text { Site } \\
\text { (depth) }\end{array}$ & Date & $\begin{array}{c}\text { No. of } \\
\text { sediment cores }\end{array}$ & Porosity & $\begin{array}{l}\text { LOI } \\
(\%)\end{array}$ & $\begin{array}{c}{\left[\mathrm{NO}_{3}^{-}\right]} \\
\left(\mu \mathrm{mol} \mathrm{l} l^{-1}\right)\end{array}$ & $\begin{array}{c}{\left[\mathrm{NH}_{4}^{+}\right]} \\
\left(\mu \mathrm{mol} \mathrm{l}^{-1}\right)\end{array}$ & $\begin{array}{c}{\left[\mathrm{PO}_{4}{ }^{3-}\right]} \\
\left(\mu \mathrm{mol} \mathrm{l^{-1 }}\right)\end{array}$ & $\begin{array}{c}{\left[\mathrm{O}_{2}\right]} \\
\left(\mu \mathrm{mol} \mathrm{l}^{-1}\right)\end{array}$ & $\begin{array}{c}\mathrm{O}_{2} \text { sat. } \\
(\%)\end{array}$ & $\begin{array}{c}T \\
\left({ }^{\circ} \mathrm{C}\right)\end{array}$ & $\mathrm{pH}$ \\
\hline \multicolumn{12}{|c|}{ Early summer } \\
\hline Lit (1 m) & 6 Jun 06 & 3 & 0.88 & 5.32 & 23.64 & 1.21 & 0.10 & 363 & 104 & 10.6 & - \\
\hline Lit (3 m) & 13 Jun 06 & 3 & 0.93 & 11.22 & 18.21 & 1.21 & 0.23 & 359 & 112 & 14.5 & 7.85 \\
\hline Pro $(8 \mathrm{~m})$ & 30 Jun 06 & 3 & 0.94 & 11.77 & 28.07 & 2.79 & 0.13 & 281 & 82 & 11.2 & 6.82 \\
\hline \multicolumn{12}{|c|}{ Mid-summer } \\
\hline Lit (1 m) & 1 Aug 06 & 3 & 0.85 & 5.45 & 3.07 & 1.21 & 0.03 & 300 & 108 & 21.3 & 8.21 \\
\hline Lit (3 m) & 3 Aug 06 & 3 & 0.94 & 9.22 & 3.14 & 1.07 & 0.03 & 288 & 103 & 20.8 & 8.81 \\
\hline Pro $(8 \mathrm{~m})$ & 10 Aug 06 & 3 & 0.94 & 11.56 & 35.07 & 7.64 & 0.03 & 194 & 56 & 10.9 & 6.59 \\
\hline \multicolumn{12}{|l|}{ Autumn } \\
\hline Lit (1 m) & $3 \& 5$ Oct 06 & $3^{a}$ & 0.87 & 6.11 & 3.09 & 1.60 & 0.03 & 319 & 96 & 12.6 & 7.17 \\
\hline Lit (3 m) & 3 Oct 06 & 3 & 0.92 & 9.54 & 8.07 & 4.71 & 0.10 & 275 & 84 & 13.0 & 7.69 \\
\hline Pro $(8 \mathrm{~m})$ & $11 \& 12$ Oct 06 & $3^{\mathrm{a}}$ & 0.92 & 9.82 & 7.48 & 2.90 & 0.06 & 321 & 95 & 12.2 & 7.62 \\
\hline \multicolumn{12}{|l|}{ Winter } \\
\hline Lit (1 m) & 3 Mar 07 & 3 & 0.86 & 6.52 & 34.29 & 0.71 & 0.16 & 453 & 100 & 0.5 & 6.94 \\
\hline Lit (3 m) & 1 Mar 07 & 3 & 0.93 & 9.27 & 36.07 & 0.93 & 0.16 & 413 & 94 & 1.4 & 7.25 \\
\hline Pro $(8 \mathrm{~m})$ & 27 Feb 07 & 3 & 0.94 & 11.46 & 36.14 & 0.93 & 0.29 & 378 & 86 & 1.5 & 7.18 \\
\hline
\end{tabular}


in incubations was always adequate to contain the whole denitrification zone (Fig. 1). The samples were enriched with $\mathrm{K}^{15} \mathrm{NO}_{3}$ (98 atom \%; Cambridge Isotope Laboratories) to a final concentration of $100 \mu \mathrm{M}$ and incubated, with a magnetic stirrer on the lid of the cores, at in situ temperature in darkness for $3 \mathrm{~h}$. Microbial activity was then terminated by adding $1 \mathrm{ml} \mathrm{ZnCl}_{2}(1 \mathrm{~g}$ $\mathrm{ml}^{-1}$ ); the samples were mixed, and subsamples of the sediment-water slurry were transferred to gas-tight glass vials (12 ml; Exetainer ${ }^{\circledR} ;$ Labco). The samples were analysed for their mass ratios of $\mathrm{N}_{2}$ using a mass spectrometer (Europa Scientific, Roboprep-G-Plus and Tracermass) at the National Environmental Research Institute in Silkeborg, Denmark. The concentration of ${ }^{15} \mathrm{NO}_{3}{ }^{-}$applied was appropriate considering the assumptions underlying IPT regarding the first-order kinetics of the formation of labelled $\mathrm{N}_{2}$ (D15, see below) and the independence of the measured denitrification rates of natural ${ }^{14} \mathrm{NO}_{3}{ }^{-}$(D14, see below) from the amount of added $\left[{ }^{15} \mathrm{NO}_{3}^{-}\right]$. We tested these assumptions in October 2006 with sediments from 2 sampling stations by applying ${ }^{15} \mathrm{NO}_{3}{ }^{-}$in concentrations of 50, 100 and $200 \mu \mathrm{M}$ (Fig. A1 in Appendix 1).

The denitrification rate was calculated from the ratios of ${ }^{29} \mathrm{~N}_{2}\left({ }^{14} \mathrm{~N}^{15} \mathrm{~N}\right)$ and ${ }^{30} \mathrm{~N}_{2}\left({ }^{15} \mathrm{~N}^{15} \mathrm{~N}\right)$, which are formed during the isotopic pairing. These ratios were calculated by dividing the currents of ${ }^{29} \mathrm{~N}_{2}$ and ${ }^{30} \mathrm{~N}_{2}$, given by the mass spectrometer, by the current of total $\mathrm{N}_{2}\left({ }^{28} \mathrm{~N}_{2},{ }^{29} \mathrm{~N}_{2},{ }^{30} \mathrm{~N}_{2}\right.$ combined). Non-incubated control samples were analysed concurrently with the incubated samples. The isotopic ratios of non-incubated control samples were subtracted from those of incubated samples to calculate the excess of ${ }^{29} \mathrm{~N}_{2}$ and ${ }^{30} \mathrm{~N}_{2}$ produced during incubations. The concentration of $\mathrm{N}_{2}$ in the vial was determined from mass spectrometer signals of concurrently analysed standard samples of $\mathrm{N}_{2}$. Calculations of D15 (denitrification rate of added ${ }^{15} \mathrm{NO}_{3}{ }^{-}$), D14 (denitrification rate of natural ${ }^{14} \mathrm{NO}_{3}{ }^{-}$), $\mathrm{D}_{\mathrm{w}}$ (denitrification of the ${ }^{14} \mathrm{NO}_{3}{ }^{-}$in the water overlying the sediment) and $\mathrm{D}_{\mathrm{n}}$ (denitrification of the ${ }^{14} \mathrm{NO}_{3}{ }^{-}$produced in the sediment via nitrification) (Nielsen 1992) were made according to Tuominen et al. (1998). The $\left[\mathrm{NO}_{3}{ }^{-}\right]$values used in calculations were assumed to be approximately the same as combined $\left[\mathrm{NO}_{3}{ }^{-}+\mathrm{NO}_{2}{ }^{-}\right]$. The denitrification rates obtained were converted to $\mu \mathrm{mol} \mathrm{N} \mathrm{m}^{-2} \mathrm{~d}^{-1}$ by multiplying by the total volume of the sample (= volume of the water phase + volume of sediment $\times$ porosity) and dividing by the surface area of the sample and the incubation time.

Data on denitrification rates, hypolimnetic nitrate concentrations, and the geographical locations of previously studied lakes were collected to aid in the interpretation of the results of our study. The data were compiled from various review articles (Table 1 in Seitzinger 1988, Table 5 in Saunders \& Kalff 2001b,
Tables 1 \& 2 in Piña-Ochoa \& Álvarez-Cobelas 2006) and single studies (Ahlgren et al. 1994, Mengis et al. 1997, Nõges et al. 1998, Risgaard-Petersen et al. 1999, Svensson et al. 2001, De Medina et al. 2003, Schernewski 2003, Hasegawa \& Okino 2004, Müller et al. 2005, McCarthy et al. 2007, Sollie \& Verhoeven 2008, Nizzoli et al. 2010). Hypolimnetic nitrate concentrations of Nizzoli et al. (2010) and Ahlgren et al. (1994) were kindly provided by D. Nizzoli and I. Ahlgren, respectively.

Molecular microbiological characterizations. Denitrification communities were studied from the total of 36 samples representing each field replicate core collected for the denitrification incubations. Three sediment subsamples (depth of 0 to $1 \mathrm{~cm}$ ) of $5 \mathrm{ml}$ each were taken with a pipette around the incubation tubes and pooled into small sterile glass vials. From the vials, $200 \mu \mathrm{l}$ samples were taken into small sterile plastic tubes and these were immediately stored at $-20^{\circ} \mathrm{C}$ for subsequent transport in dry ice to the University of Jyväskylä, Department of Environmental and Biological Sciences, where the samples were stored at $-80^{\circ} \mathrm{C}$ before extraction of nucleic acid within 1 to 5 mo. According to previous studies, the sampled depth always contained most of the denitrification zone (Fig. 1). Nucleic acids were extracted from samples using a modified version of the protocol of Griffiths et al. (2000) (see Rissanen et al. 2010 for further details).

For DGGE analysis, PCR amplification of $472 \mathrm{bp}$ fragments of nirK was carried out from DNA extractions using the following primer pairs suggested by Throbäck et al. (2004): F1aCu (5'-ATC ATG GT[C/G] CTG CCG CG-3')/R3Cu (5'-GCC TCG ATC AG[A/G] TTG TGG TT-3') (Hallin \& Lindgren 1999) with a GCclamp (GGC GGC GCG CCG CCC GCC CCG CCC CCG TCG CCC) attached to the 5' end of $\mathrm{R} 3 \mathrm{Cu}$. In the PCR reaction, $1 \mu \mathrm{l}$ of nucleic acid extract was used as a template in a $25 \mu \mathrm{l}$ PCR mixture containing $0.2 \mathrm{mM}$ of dNTPs, $0.3 \mu \mathrm{M}$ of each primer, $1 \times$ Biotools reaction buffer, $1 \mathrm{mg} \mathrm{ml}^{-1}$ bovine serum albumin (BSA) and $0.25 \mathrm{U}$ Biotools polymerase. PCR amplification was performed in a GeneAmp PCR system 9600 (Perkin Elmer) with an initial denaturation step at $95^{\circ} \mathrm{C}$ for $5 \mathrm{~min}$ and 35 cycles of amplification $\left(94^{\circ} \mathrm{C}\right.$ for $30 \mathrm{~s}, 53^{\circ} \mathrm{C}$ for $1 \mathrm{~min}, 72^{\circ} \mathrm{C}$ for $3 \mathrm{~min}$ ).

DGGE was carried out in an Ingeny Phor electrophoresis unit (Ingeny) at $100 \mathrm{~V}$ for $18 \mathrm{~h}$ in $6 \%$ polyacrylamide gels (acrylamide/bisacrylamide) submerged in 0.5 M TAE-buffer (40 mM Tris- $\mathrm{HCl} \mathrm{pH} 7.4$, $20 \mathrm{mM}$ sodium acetate, $1 \mathrm{mM} \mathrm{Na}{ }_{2}$ EDTA) at $60^{\circ} \mathrm{C}$. The linear gradient of denaturating conditions (urea and formamide) determined from a preliminary analysis using a wide denaturant gradient (20 to $80 \%$ ) was 40 to $70 \%(100 \%$ denaturant was defined as $7 \mathrm{M}$ urea and $40 \%$ formamide) (Muyzer et. al. 1993). After elec- 
trophoresis the gel was stained with ethidium bromide $\left(0.5 \mathrm{mg} \mathrm{l}^{-1}\right)$, illuminated in UV light and photographed. Image analysis was done using the Quantity One software package (BioRad). DNA density curves for each lane were created after a rolling disc backround subtraction, and bands were recognized semi-automatically. Bands with the same migratory distances in each lane were regarded as representing the same operational taxonomic unit (OTU). The relative abundance of each OTU of all the OTUs in each lane were quantified as a ratio of the total peak area for all peaks in a lane and converted into percentages by multiplying by 100. To confirm that DGGE bands represented real nirK sequences, samples of 3 of the dominant OTUs were taken from the gel, eluted in water, reamplified, and sequenced (BigDye Terminator v3.1 Cycle Sequencing Kit and ABI3100 capillary sequencing instrument; Applied Biosystems). DNA sequences were edited using the Contig Express program (Invitrogen), translated to protein sequences, and compared to protein databases using BLASTX software (http://blast. ncbi.nlm.nih.gov/Blast.cgi) (Altschul et al. 1997).

The sequence data have been deposited in the EMBL database (European Bioinformatics Institute, www.ebi. ac.uk/embl/) under accession numbers FN811666 to FN811668.

Statistical analyses. The average of D14, $D_{w}, D_{n}$ $\mathrm{D}_{\mathrm{w}} \%$ and $\mathrm{D}_{\mathrm{n}} \%$ of the 3 incubation tubes taken from each field replicate core were treated as replicates in statistical analyses (i.e. $\mathrm{n}=3$ for each Season/Site combination). Analysis of variation in D14 was based on a factorial design, with both Season and Site as fixed factors $(\alpha=0.05)$ in analysis of variance (ANOVA). Because of a significant interaction between factors (see 'Results') we analysed simple effects of spatial differences separately at each level of Season, and temporal differences separately at each level of Site (Quinn \& Keough 2002). Simple effects were studied using $F$-tests followed by pair-wise comparisons using the least significant difference (LSD) technique with Hochberg-Bonferroni (Hochberg 1988) corrected $\alpha$ values in each partial test. Correlations among different environmental factors and D14, $\mathrm{D}_{\mathrm{w}}, \mathrm{D}_{\mathrm{n}}, \mathrm{D}_{\mathrm{w}} \%$ and $\mathrm{D}_{\mathrm{n}} \%$ were studied using Spearman correlation analysis. Statistical analyses were conducted using SPSS 14.0 (SPSS).

Multivariate analyses of data from the DGGE examination of nirK were based on Bray-Curtis dissimilarities calculated among samples using square-roottransformed data of relative percentage abundances of OTUs. Analogous to the analysis of denitrification rates, the spatial and temporal variations in the structure of the nirK-carrying communities were analysed using permutational multivariate analysis of variance (PERMANOVA, 9999 permutations) (Anderson 2001,
McArdle \& Anderson 2001) by applying a factorial design with both Season and Site as fixed factors. Because of the limited number of replicates, the PERMANOVA p-values of pair-wise tests were estimated using Monte Carlo random draws from the asymptotic permutation distribution. Data from the nirK-containing community were further assessed graphically using non-metric multidimensional scaling (NMDS). The NMDS was constrained to 2 ordination axes. To minimize the Kruskall's stress and to avoid local minimum solutions, NMDS was performed with 100 runs with the real data, a random starting configuration in each run, and an instability criterion of 0.0001 . Monte Carlo tests of the real data versus randomized data (200 runs with randomized data) were used to assess the significance of the solution. A final solution with minimum stress $(13.2 \%)$ was achieved with 82 iterations. The relationship between environmental factors and the structure of the nirK-containing community was analysed at both community and single-OTU levels using a distance-based linear model (DISTLM) procedure (Anderson 2001, McArdle \& Anderson 2001) and Spearman correlation analysis, respectively. Environmental variables were analysed separately for their relationships with DGGE data. Because $\mathrm{pH}$ was not measured at the shallow littoral site in early summer, these samples were excluded when analyzing the relationship between $\mathrm{pH}$ and DGGE data. The possible effect of community structure on the D14 rates was studied at the community level using Mantel's test by comparing the relationships of distance matrices generated from the community structure data (Bray-Curtis) and process measurement data (Euclidean distance), and at the singleOTU level using Spearman correlation analysis. NMDS and Mantel's test were performed using PCORD version 4.01 (B. McCune and M. J. Mefford, PCORD for Windows: multivariate analysis of ecological data, 4.01 ed, MjM Software, Gleneden Beach, Oreggon, USA, 1999), PERMANOVA and DISTLM using respective programs freely available from the website: www.stat.auckland.ac.nz/ mja/Programs.htm.

\section{RESULTS}

\section{Environmental factors}

The sampled sites differed from each other, with sediment at the shallow littoral site $(1 \mathrm{~m})$ having considerably lower porosity and LOI (i.e. organic matter content) than sediment at the other 2 sites. In general, the deeper littoral site $(3 \mathrm{~m})$ was more similar to the profundal site $(8 \mathrm{~m})$ than to the shallow littoral site (Table 1). There was some seasonal variation in the 
organic content of sediment, with LOI increasing steadily in the shallow littoral $(1 \mathrm{~m})$ and being considerably higher during early summer than during the rest of the year in the deep littoral zone $(3 \mathrm{~m})$. LOI in the profundal zone was considerably lower in autumn than during the rest of the year. In the deep littoral there were visible clumps of algae on the sediment surface during all seasons, except for winter, whereas at the other sites algae were not observed.

The physicochemical characteristics of the water reflected the general seasonality of boreal lakes (Table 1). In mid-summer, both of the littoral sites were epilimnetic, and, based on measurements of vertical temperature profiles at the deepest area of the lake at 1 to 2 wk before our sampling (26 July) (Jäntti 2007), the profundal site was located at the thermocline. In mid-summer there was over-saturation of oxygen in the littoral zone. Also, $\mathrm{pH}$ and oxygen concentrations were higher, and inorganic nitrogen concentration lower, in the littoral sites than in the profundal zone (Table 1), which probably reflects vigorous primary production. In autumn, the chemical differences among sites diminished in the profundal zone oxygen was replenished, $\mathrm{pH}$ and temperature raised, and inorganic nitrogen concentrations lowered; in the littoral sites, $\mathrm{pH}$ and temperature were lower; and in the deep littoral site concentrations of inorganic nitrogen had increased. At all sites, winter was characterized by very low temperatures, high concentrations of oxygen and nitrate, and very low concentrations of ammonium. in the profundal zone during mid-summer. In autumn, there were no significant spatial differences in D14 ( $F$ $=2.9, \mathrm{p}>0.05)$. In winter, the highest rates were observed in the shallow and deep littoral zones. In the shallow littoral zone, D14 was highest during early summer and winter, with significant differences between early summer and autumn and between winter and mid-summer and winter and autumn. In the deep littoral zone there were no significant temporal differences after the stringent Hochberg-Bonferroni correction of $\alpha$-values. In the profundal zone, D14 peaked during mid-summer but was very stable during the other seasons. On most occasions, D14 was dominated by $D_{n}$ (Fig. 2). The change in D14 from early summer to mid-summer was due to an increase in $D_{n}$ and a decrease in $\mathrm{D}_{\mathrm{w}}$ in the littoral zones, whereas $\mathrm{D}_{\mathrm{w}}$ increased in the profundal zone. In autumn, the decrease in D14 was due to a decrease in $\mathrm{D}_{\mathrm{n}}$ in the littoral zones and an increase in $\mathrm{D}_{\mathrm{w}}$ in the deep littoral zone, whereas $\mathrm{D}_{\mathrm{w}}$ decreased in the profundal zone. In winter, the increase in D14 in the littoral zone was due mainly to the considerable increase in $D_{n}$.

D14 increased when the concentration of nitrate in the water increased and the temperature and $\mathrm{pH}$ decreased (Table 2). $\mathrm{D}_{\mathrm{w}}$ increased when the concentration of ammonium in the water increased and the $\mathrm{pH}$ decreased. There was also a slight but statistically not significant tendency of $D_{w}$ to increase when the concentration of nitrate increased and oxygen saturation and temperature decreased. $\mathrm{D}_{\mathrm{n}}$ did not correlate sig-

\section{Denitrification rates}

D14, $D_{\mathrm{w}}$, and $\mathrm{D}_{\mathrm{n}}$ rates in single incubation tubes varied from 44 to 613 , from 18 to 429 and from 0.8 to $346 \mu \mathrm{mol} \mathrm{N} \mathrm{m}{ }^{-2} \mathrm{~d}^{-1}$, respectively. For the field replicates, i.e. the sample cores, the range was from 52 to 577,22 to 414 , and 18 to $264 \mu \mathrm{mol} \mathrm{N} \mathrm{m}{ }^{-2}$ $\mathrm{d}^{-1}$ with average values of 220,108 and $112 \mu \mathrm{mol} \mathrm{N} \mathrm{m}{ }^{-2} \mathrm{~d}^{-1}$, respectively. There was a significant interaction between Site and Season in D14 $(F=17.6, \mathrm{p}<0.001)$ indicating that the temporal variation was different at different sites (Fig. 2). Analysis of simple effects revealed that both site and season affected D14 (effect of Season: shallow littoral, $F=8.7, \mathrm{p}<0.001$; deep littoral, $F=3.0, \mathrm{p}<0.05$; profundal, $F=41.4$, $\mathrm{p}<0.001$; effect of Site: early summer, $F=$ $4.6, \mathrm{p}<0.05$; mid-summer, $F=62.0, \mathrm{p}<$ 0.001 ; winter, $F=4.5, \mathrm{p}<0.05)$. D14 rates were highest in the shallow littoral and profundal zones during early summer and

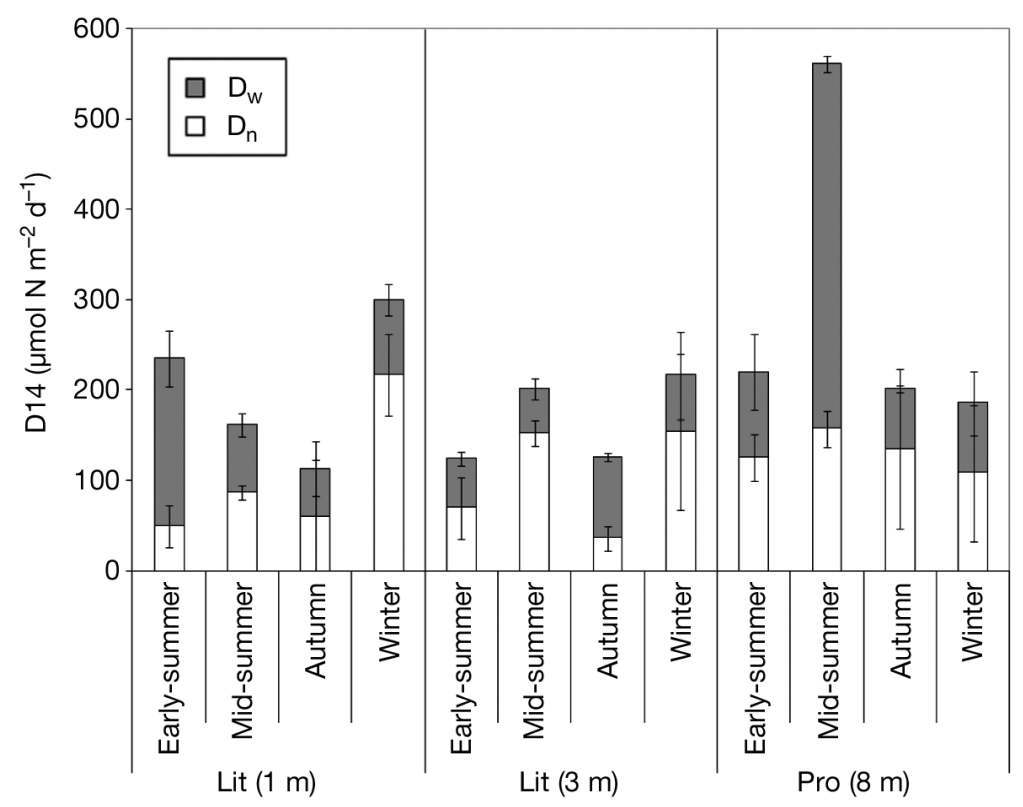

Fig. 2. Spatial and seasonal variations of mean $( \pm \mathrm{SD})$ sediment D14 (denitrification of the natural $\left.{ }^{14} \mathrm{NO}_{3}^{-}\right)\left(\mu \mathrm{mol} \mathrm{N} \mathrm{m} \mathrm{N}^{-2} \mathrm{~d}^{-1}\right)$ divided into $\mathrm{D}_{\mathrm{w}}$ (denitrification of the ${ }^{14} \mathrm{NO}_{3}{ }^{-}$in the water overlying the sediment) and $\mathrm{D}_{\mathrm{n}}$ (denitrification of the ${ }^{14} \mathrm{NO}_{3}{ }^{-}$produced in the sediment via nitrification) in Lake Ormajärvi in the period 2006 to 2007 
Table 2. Correlations (Spearman's rho) of different denitrification parameters and environmental factors (see Table 1 for definitions). D14 = denitrification rate of natural ${ }^{14} \mathrm{NO}_{3}{ }^{-} ; \mathrm{D}_{\mathrm{w}}=$ denitrification of the ${ }^{14} \mathrm{NO}_{3}{ }^{-}$of the water overlying the sediment; $\mathrm{D}_{\mathrm{w}} \%=$ proportion of $\mathrm{D}_{\mathrm{w}}$ of $\mathrm{D} 14 ; \mathrm{D}_{\mathrm{n}}=$ denitrification of the ${ }^{14} \mathrm{NO}_{3}{ }^{-}$produced in the sediment via nitrification; $\mathrm{D}_{\mathrm{n}} \%=$ proportion of $\mathrm{D}_{\mathrm{n}}$ of D14. Correlation coefficients with $\mathrm{p}<0.05$ and $0.05<\mathrm{p}<0.10$ are written in bold and normal text, respectively. $\mathrm{n}=36$, except for analyses of $\mathrm{pH}$, where $\mathrm{n}=33$

\begin{tabular}{|lcccccccccccc|}
\hline & $\mathrm{D} 14$ & $\mathrm{D}_{\mathrm{w}}$ & $\mathrm{D}_{\mathrm{n}}$ & $\mathrm{D}_{\mathrm{w}} \%$ & $\mathrm{D}_{\mathrm{n}} \%$ & {$\left[\mathrm{NO}_{3}{ }^{-}\right]$} & {$\left[\mathrm{NH}_{4}{ }^{+}\right]$} & {$\left[\mathrm{PO}_{4}{ }^{3-}\right]$} & {$\left[\mathrm{O}_{2}\right]$} & $\mathrm{O}_{2}$ sat. $(\%)$ & $\mathrm{pH}$ & LOI \\
\hline $\mathrm{D}_{\mathrm{w}}$ & $\mathbf{0 . 4 2}$ & & & & & & & & & & & \\
$\mathrm{D}_{\mathrm{n}}$ & $\mathbf{0 . 7 9}$ & - & & & & & & & & & & \\
$\mathrm{D}_{\mathrm{w}} \%$ & - & $\mathbf{0 . 6 8}$ & $-\mathbf{0 . 7 1}$ & & & & & & & & & \\
$\mathrm{D}_{\mathrm{n}} \%$ & - & $\mathbf{- 0 . 6 8}$ & $\mathbf{0 . 7 1}$ & $\mathbf{- 1 . 0 0}$ & & & & & & & & \\
{$\left[\mathrm{NO}_{3}{ }^{-}\right]$} & $\mathbf{0 . 4 5}$ & 0.32 & 0.32 & - & - & & & & & & & \\
{$\left[\mathrm{NH}_{4}{ }^{+}\right]$} & - & $\mathbf{0 . 3 8}$ & - & $\mathbf{0 . 5 1}$ & $-\mathbf{0 . 5 1}$ & - & & & & & & \\
{$\left[\mathrm{PO}_{4}{ }^{3-}\right]$} & - & - & - & - & - & $\mathbf{0 . 6 8}$ & $\mathbf{- 0 . 4 7}$ & & & & & \\
{$\left[\mathrm{O}_{2}\right]$} & - & - & - & -0.30 & 0.30 & $\mathbf{0 . 3 9}$ & $\mathbf{- 0 . 8 2}$ & $\mathbf{0 . 6 3}$ & & & & \\
$\mathrm{O}_{2}$ sat. $(\%)$ & - & -0.31 & - & - & - & $\mathbf{- 0 . 4 7}$ & $\mathbf{- 0 . 4 1}$ & - & $\mathbf{0 . 4 3}$ & & & \\
$\mathrm{pH}$ & $\mathbf{- 0 . 5 3}$ & $\mathbf{- 0 . 5 1}$ & -0.32 & - & - & $\mathbf{- 0 . 6 5}$ & - & - & - & $\mathbf{0 . 6 9}$ & & \\
$T$ & $-\mathbf{0 . 5 2}$ & -0.31 & -0.32 & - & - & $\mathbf{- 0 . 8 5}$ & $\mathbf{0 . 3 9}$ & $\mathbf{- 0 . 5 4}$ & $\mathbf{- 0 . 5 9}$ & $\mathbf{0 . 3 8}$ & $\mathbf{0 . 7 8}$ & \\
LOI & - & - & - & - & - & $\mathbf{0 . 4 9}$ & $\mathbf{0 . 3 8}$ & $\mathbf{0 . 3 4}$ & $\mathbf{- 0 . 3 6}$ & $\mathbf{- 0 . 6 5}$ & $\mathbf{- 0 . 4 8}$ & \\
Porosity & - & - & - & - & - & $\mathbf{0 . 3 6}$ & - & - & $\mathbf{- 0 . 3 4}$ & $\mathbf{- 0 . 4 1}$ & - & $\mathbf{0 . 7 1}$ \\
\hline
\end{tabular}

nificantly with any of the variables measured. There was, however, a slight tendency towards an increase in $\mathrm{D}_{\mathrm{n}}$ when the concentration of nitrate increased and the $\mathrm{pH}$ and temperature decreased. $\mathrm{D}_{\mathrm{w}} \%$ increased, and $\mathrm{D}_{\mathrm{n}} \%$ decreased, when the concentration of ammonium increased. A slight tendency towards an increase in $\mathrm{D}_{\mathrm{w}} \%$ and a decrease in $\mathrm{D}_{\mathrm{n}} \%$ was also detected when the concentration of oxygen decreased. Nitrate concentrations correlated positively with sediment porosity, LOI and concentrations of phosphate and oxygen, and negatively with $\mathrm{pH}$, temperature and oxygen saturation (Table 2). Ammonium concentrations correlated positively with temperature and LOI and negatively with oxygen saturation and concentrations of phosphate and oxygen.

\section{Denitrifier community}

DGGE analysis of the nirK-carrying community revealed 27 nirK bands, here referred to as OTUs (Fig. 3A). The DGGE profiles were very similar from different sites and seasons, with more variation among sites than among seasons. Most of the OTUs, 21 of 27 , were shared between the sites during all seasons. Variations in the presence/absence of only 6 OTUs separated the community structure among sites (Fig. 3A). Three OTUs were unique to the shallow littoral site. Two OTUs were unique to both the deep littoral and profundal sites, and one OTU was unique to the profundal site.

There was a slight but statistically significant interaction between Site and Season in the structure of the nirK-containing community (PERMANOVA, $F=$ 1.84, $\mathrm{p}<0.01)$, but with each site analysed separately the community did not differ among seasons ( $p>0.05)$. However, the nirK-containing community differed among sites (PERMANOVA, $\mathrm{F}=9.27, \mathrm{p}<0.001$; pairwise comparisons, $\mathrm{p}<0.05)$. Visualization of the community structure by NMDS confirmed the results of PERMANOVA analyses; the different sites were well separated in the direction of increasing depth, with more overlap between deep littoral and profundal sites than between shallow and deep littoral sites, and the temporal variations were very minor (Fig. 3B).

The variation in the structure of the nirK-containing community was clearly most dependent on variation in sediment porosity and LOI (Table 3 \& Table A1 in Appendix 1); these variables were also highly intercorrelated (Table 2). Much less variation in community structure was explained by variations in water variables, i.e. oxygen saturation, $\mathrm{pH}$ and the concentrations of inorganic nitrogen and phosphorus (Tables 3 \& A1). However, these variables were also correlated with sediment characteristics (Table 2) and therefore this can also be explained by co-variation. We detected no indication of an effect of the composition of the nirK-containing community on D14; the abundance of only 1 nirK OTU correlated slightly with D14 at the single-OTU level (Table A1), and there was no correlation between community composition and D14 at the community level (Mantel's test: $r=0.03, p>0.05$ ).

The translated protein sequences of bands extracted from the DGGE gel, representing OTUs 3, 11 and 12 (Fig. 3A), shared 93, 99 and $100 \%$ identities to the closest matched environmental NirK sequences but only 86,85 and $66 \%$ identities to the closest matching NirK sequences of cultivated organisms affiliated to Silicibacter sp. TrichCH4B, Silicibacter sp. TrichCH4B, and Sinorhizobium medicae WSM419, respectively. 

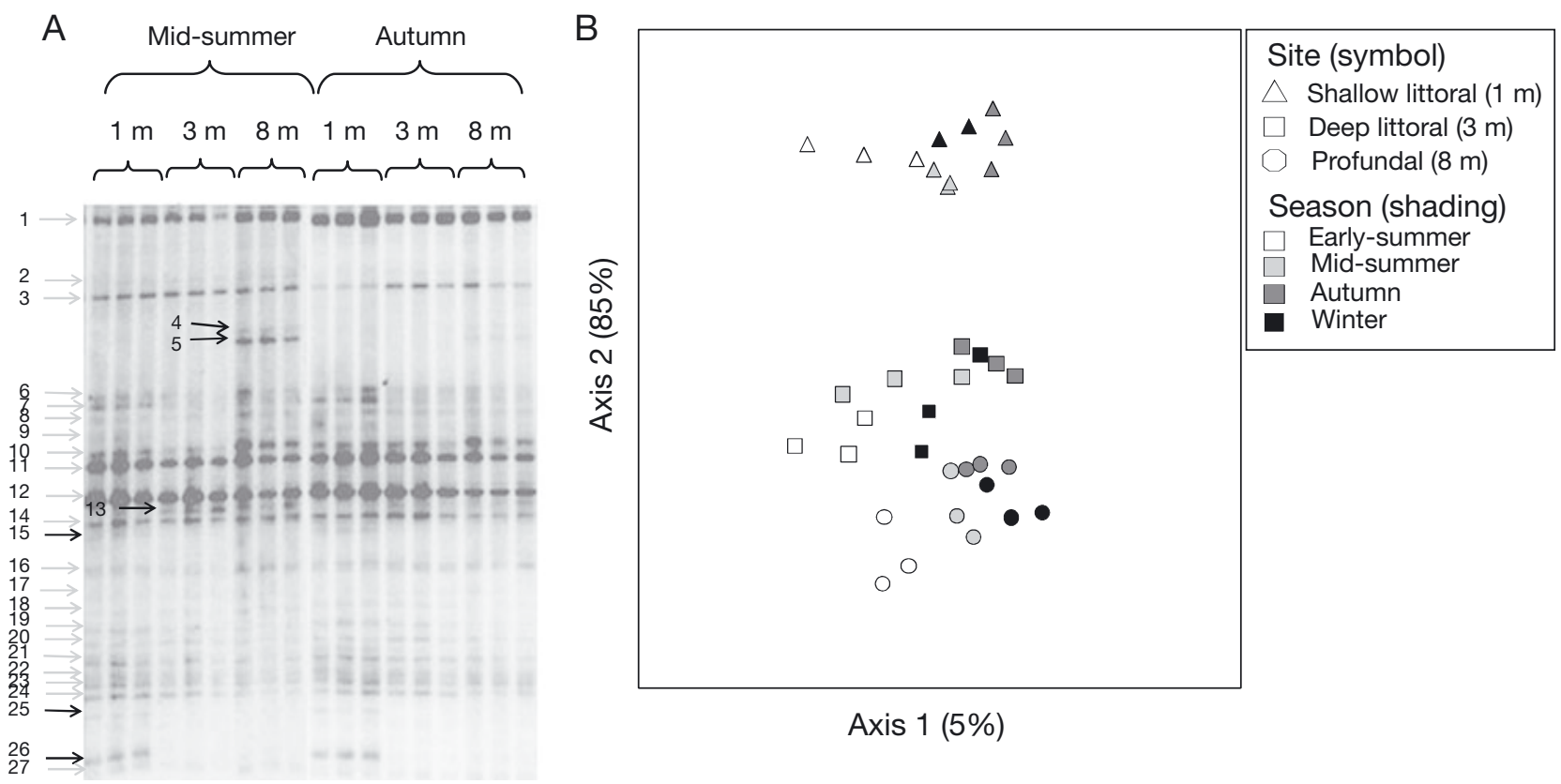

Axis $1(5 \%)$

Fig. 3. (A) Some of the results from the examination of nirK by denaturing-gradient gel electrophoresis (DGGE), and (B) nonmetric multidimensional scaling (NMDS) results from data obtained from the examination of nirK by DGGE. In (A), the arrows point to the 27 operational taxonomic units (OTUs) (bands) detected. OTUs marked with a grey arrow were detected from every sample at each site in all seasons. OTUs marked with a black arrow were detected at particular sites only; in samples from either a littoral (1 m) site in all seasons (OTUs 15, 25 and 26), or only from littoral (3 m) and profundal (8 $\mathrm{m})$ sites in all seasons (OTU 13), a profundal $(8 \mathrm{~m})$ site in all seasons (OTUs 4 and 5 ) or a littoral $(3 \mathrm{~m})$ site in early summer and winter (OTU 5)

Table 3. Results of distance-based linear model (DISTLM) analyses on relationships between the structure of the nirKcontaining community and individual environmental factors (see Table 1 for definitions). Prop. = the proportion of variance in the community structure explained by the environmental

factor. $\mathrm{n}=35$, except for analyses of $\mathrm{pH}$, where $\mathrm{n}=32$

\begin{tabular}{|lccc|}
\hline Variable & $F$ & $p$ & Prop. \\
\hline LOI & 25.6 & 0.0001 & 0.44 \\
Porosity & 24.6 & 0.0001 & 0.43 \\
$\mathrm{O}_{2}$ saturation (\%) & 6.0 & 0.0005 & 0.15 \\
{$\left[\mathrm{NH}_{4}{ }^{+}\right]$} & 3.5 & 0.0093 & 0.10 \\
{$\left[\mathrm{NO}_{3}{ }^{-}\right]$} & 3.0 & 0.0253 & 0.08 \\
$\mathrm{pH}^{\left[\mathrm{PO}_{4}{ }^{3-}\right]}$ & 2.8 & 0.0299 & 0.08 \\
{$\left[\mathrm{O}_{2}\right]^{\mathrm{T}}$} & 2.5 & 0.0483 & 0.07 \\
& 2.0 & 0.0863 & 0.06 \\
& 1.1 & 0.3082 & 0.03 \\
\hline
\end{tabular}

\section{DISCUSSION}

Denitrification rates are, on average, higher in freshwater ecosystems than in estuaries, coastal ecosystems and oceans (Piña-Ochoa \& Álvarez-Cobelas 2006), and rates reported from lacustrine sediments range from 0 to $15000 \mu \mathrm{mol} \mathrm{N} \mathrm{m}{ }^{-2} \mathrm{~d}^{-1}$ (Fig. 4A). Although denitrification rates are usually higher in eutrophic lakes than in oligotrophic lakes (Seitzinger 1988, Saunders \& Kalff 2001b), the rates we measured in Lake Ormajärvi (D14 varied between 44 and $613 \mu \mathrm{mol} \mathrm{N} \mathrm{m}{ }^{-2} \mathrm{~d}^{-1}$ ) are among the lowest ever reported from lacustrine sediments (e.g. Seitzinger 1988, Saunders \& Kalff 2001b). The result cannot be explained by differing methods (cf. Groffman et al. 2006), as the same holds true when comparing our rates specifically with those of other lacustrine IPT studies $\left(\sim 0\right.$ to $\left.4300 \mu \mathrm{mol} \mathrm{N} \mathrm{m} \mathrm{N}^{-2} \mathrm{~d}^{-1}\right)$ (Fig. 4B). However, previous studies have usually been conducted in lakes at lower latitudes, between $40^{\circ} \mathrm{N}$ and $58^{\circ} \mathrm{N}$, and our study is among the few carried out in the boreal zone (Fig. 4A). Indeed, our rates do compare well with those from IPT studies in Lakes Norrviken and Vallentuna ( 0 to $\sim 600 \mu \mathrm{mol} \mathrm{N} \mathrm{m}{ }^{-2} \mathrm{~d}^{-1}$ ) in central Sweden (Ahlgren et al. 1994). Our rates also agree with those measured for sediments from the open sea areas of the northern Baltic Sea (Tuominen et al. 1998) and from a coastal station in the Gulf of Finland (Hietanen \& Kuparinen 2008), and they are only slightly lower than in the river estuaries of the northern Baltic Sea (Silvennoinen et al. 2007). The nitrate concentration of water overlying the sediment has been shown to affect denitrification rates positively (Risgaard-Petersen et al. 1999, Hasegawa \& Okino 2004, Piña-Ochoa \& Álvarez-Cobelas 2006), and the lower process rates in lakes of the northern boreal zone compared to those in the temperate zone can be explained 

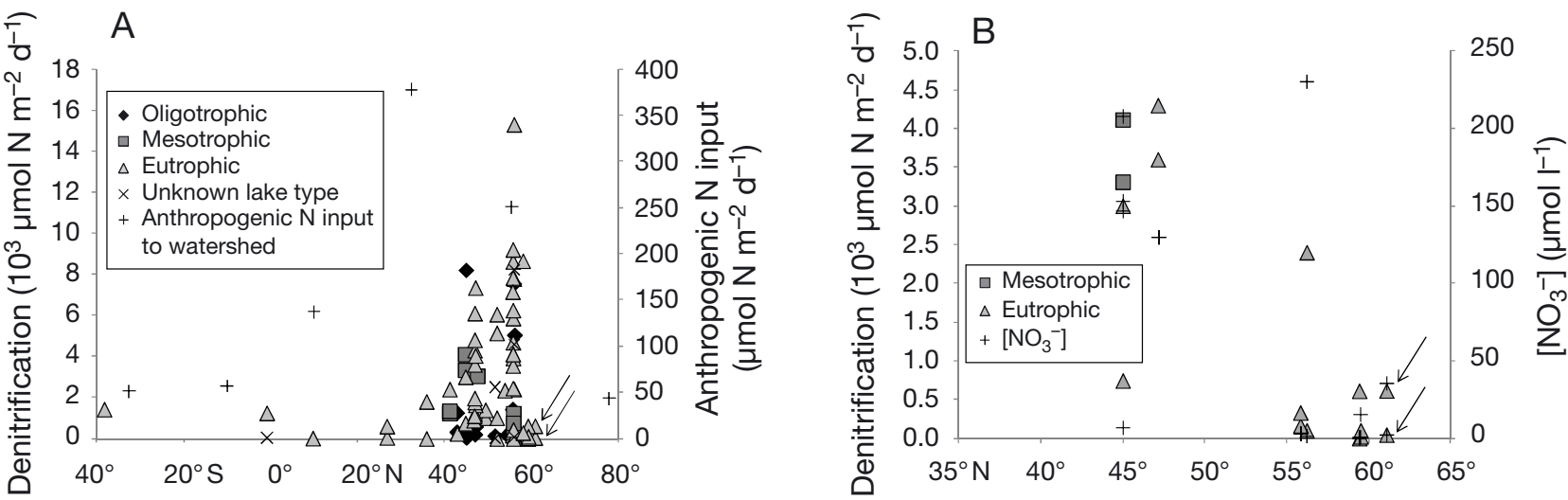

Latitude

Fig. 4. Denitrification rates ( $\mu \mathrm{mol} \mathrm{N} \mathrm{m} \mathrm{N}^{-2} \mathrm{~d}^{-1}$ ) in lakes at different latitudes measured using (A) various techniques, and (B) the isotope-pairing technique (IPT); these data include rates measured in Ormajärvi $\left(61^{\circ} \mathrm{N}_{4} 44\right.$ to $613 \mu \mathrm{mol} \mathrm{N} \mathrm{m}^{-2} \mathrm{~d}^{-1}$; indicated by arrows). Anthropogenic nitrogen inputs into watersheds $\left(\mu \mathrm{mol} \mathrm{N} \mathrm{m} \mathrm{N}^{-2} \mathrm{~d}^{-1}\right.$ ) at different latitudes, and concurrently measured hypolimnetic nitrate concentration in IPT studies, are also shown in (A) and (B), respectively. Data on denitrification rates and hypolimnetic nitrate concentrations have been compiled from various review articles and single studies (see 'Materials and methods'), and values for anthropogenic nitrogen inputs are adopted from Seitzinger et al. (2002). Denitrification rates are presented as the minimum and maximum values from each study, if available, or only as the reported mean

by co-varying nitrate concentrations (Fig. 4B). This is most likely caused by larger anthropogenic nitrogen loads to watersheds in temperate areas compared to those of the boreal zone (Fig. 4A).

The observation that denitrification rates were higher in the profundal zone than in the littoral zone during mid-summer was unexpected because the few previous studies on spatial variation in lacustrine denitrification rates indicate the opposite, i.e. that rates are higher in the warmer littoral zone (Lake Norrviken in Ahlgren et al. 1994, Mengis et al. 1997, Saunders \& Kalff 2001b). These contrasting results suggest that spatial variation in denitrification rates differs in different types of lake. In our study, the hotspot of denitrification was the shallow profundal zone in mid-summer, and in the light of these results we acknowledge that the spatial coverage in our study should have been extended to deeper profundal sites. The seasonal variation in denitrification in the profundal zone of Lake Ormajärvi, with high rates in mid-summer, is consistent with previous studies (Christensen \& Sørensen 1986, Ahlgren et al. 1994, Piña-Ochoa \& Álvarez-Cobelas 2006), but contrasting seasonalities, with high rates in winter, as measured from the shallow littoral zone of our study lake, have also been recorded (Risgaard-Petersen et al. 1999, Hasegawa \& Okino 2004). Thus, temporal variation also differs between different lakes, but it can also differ between different sites within lakes. Our results definitely highlight the importance of adequately covering both spatial and temporal variation in denitrification rates, when assessing the natural nitrogen removal capabilities of lake ecosystems. This qualification has not been met in most of the previous studies on lake denitrification, probably because of the highly laborious and expensive measurement techniques involved.

Variations in process rates usually stem from variations in environmental factors. None of the environmental factors we recorded had very high correlation with the denitrification rates in our study. Besides explaining between-lake variation, the nitrate concentration of the water overlying the sediment was also of the greatest importance in explaining withinlake variation in denitrification rates in this study. The oxygen concentration of the water overlying the sediment controls the relative importance of $D_{n}$ and $D_{w}$ by controlling the thickness of the oxic sediment surface (e.g. Rysgaard et al. 1994). Low levels of oxygen can favour $D_{w}$ over $D_{n}$ via a decrease in nitrification and reduction of the diffusional distance of nitrate from the water column to the denitrification zone, and vice versa (e.g. Rysgaard et al. 1994). The variation in the relative importance of $D_{w}$ and $D_{n}$ components, and the slight negative relationship between oxygen saturation and $\mathrm{D}_{\mathrm{w}}$ and $\mathrm{O}_{2}$ concentration and $\mathrm{D}_{\mathrm{w}} \%$, indicates that oxygen concentrations also affected the denitrification rates. We suggest that the inverse relationship between denitrification rates and temperature, which is in contrast with most studies on the effect of temperature on denitrification rates (Ahlgren et al. 1994, Saunders \& Kalff 2001b, Piña-Ochoa \& ÁlvarezCobelas 2006), is due to concurrent variations in the availability of nitrate and oxygen concentrations 
affecting the denitrification rates. We further suggest that the low rates in the littoral zone in mid-summer during the time of highest temperatures were due to photosynthetically active free-living and periphytic algae, which competed with nitrifiers and denitrifiers for inorganic nitrogen (Rysgaard et al. 1995). Nitrogen fixation, indicating nitrogen limitation, was observed in the epilimnion of Lake Ormajärvi 2 wk before our sampling and confirms our suggestions (Jäntti 2007). The coincident high rates in the profundal zone can be explained by high levels of nitrate and low levels of oxygen increasing $D_{w}$. Low levels of oxygen probably also increased the flux of ammonium from sediment to the overlying water (e.g. Cowan et al. 1996), which would explain the concurrent high concentrations of ammonium and the negative dependency between ammonium and oxygen concentrations. In addition, the high concentration of oxygen during winter probably positively affected nitrification rates, which led to a high share of $D_{n}$ and a high concentration of nitrate and a low concentration of ammonium in the water overlying the sediment. Spatial differences in denitrification rates can also be due to heterogeneity in the content of organic matter in the sediment (Saunders \& Kalff 2001b), but we did not observe that. Variations in the quality of organic matter can also result in variation in denitrification rates (Hietanen \& Kuparinen 2008), i.e. the high rates in the shallow littoral zone in early summer and winter, and in the deep littoral zone in winter, may have been due to easily degradable Typha latifolia and periphyton litter.

The composition of some previously studied denitrifier communities correlated with denitrification activity, i.e. the nirK-containing community in agricultural soil (Wertz et al. 2009) and the nosZ-containing community in estuarine sediment (Magalhães et al. 2008), while that of others did not (Rich \& Myrold 2004, Enwall et al. 2005, Boyle et al. 2006, Cao et al. 2008). This indicates that denitrification activity may, in some cases, be affected by denitrifier community composition, but in other cases environmental factors are the dominant determinants (Wallenstein et al. 2006). The uncoupling of the nirK-containing community structure and denitrification activity suggests that the denitrification in Lake Ormajärvi is controlled more by environmental factors than by the structure of the nirKcontaining community. Changes in environmental conditions may more immediately modify the denitrification rate, but may influence the community composition of denitrifiers in the longer term (Wallenstein et al. 2006). The seasonal variations in the environmental factors were large in Lake Ormajärvi, but the seasonal variations in the nirK-containing community were insignificant; this contrasts with previous studies of
nirK-containing communities in aquatic sediments (Fortunato et al. 2009) and agricultural land (Wolsing \& Priemé 2004, Wertz et al. 2009), and of nosZ-containing communities in sediments (Scala \& Kerkhof 2000, Magalhães et al. 2008) that showed marked seasonal variations, but agrees with a study showing seasonal stability of an nirK-containing community in a hypersaline microbial mat (Desnues et al. 2007). This indicates that the response of denitrifier communities to variations in environmental factors may differ between different environments. The results imply that the structure of the nirK-containing community in our study lake does not respond to seasonal variations in environmental factors and is regulated mainly by factors acting in a spatial scale, i.e. spatial variations in the sediment's content of organic matter, and structure (porosity), which have also previously been shown to affect the composition of microbial communities (e.g. Wallenstein et al. 2006, Wu et al. 2008). It is also possible that the response to environmental factors may vary between different denitrifier groups, i.e. between nirK and nirS communities (Desnues et al. 2007, Junier et al. 2008, Kim et al. 2011). In addition, besides community structure, as assessed by microbial community fingerprinting, the abundance of nirK-containing denitrifiers may also vary spatially and temporally (Dandie et al. 2008) and has also been noticed to correlate with denitrification activity in stream sediments $\left(\mathrm{O}^{\prime}\right.$ Connor et al. 2006). Therefore, we acknowledge that a more complete picture of variations in the denitrifier community would have been acquired by concurrent analyses of nirS-containing communities and the total abundance of denitrification genes.

In conclusion, the denitrification rates we measured from the boreal Lake Ormajärvi are among the lowest ever reported from lacustrine sediments. Denitrification rates varied spatially as well as seasonally, being highest during mid-summer in the profundal zone, and during winter in the littoral zones. These variations were explained by the availability of nitrate and the concentration of oxygen and, possibly, by the amount of labile organic matter. The structure of the nirKcontaining community was temporally very stable, but differed slightly between study sites. This spatial variation is presumably a result of variations in the content of organic matter in the sediment and the porosity of the sediment. The structure of the nirK-containing community did not affect denitrification rates. This study has been one of the most thorough efforts to reveal the temporal and spatial variations and their controlling factors in lacustrine denitrification, and in the denitrifier communities. Showing the variability in the rate measurements, it calls for more efficient and integrative methods for the analysis of denitrification in lakes. 
Acknowledgements. We acknowledge the Lammi Biological Station, University of Helsinki, where all the analyses as well as denitrification incubations were performed. This study was funded by the Finnish Cultural Foundation, Maa- ja Vesitekniikan tuki ry and Maj and Tor Nessling Foundation. We thank D. Nizzoli and I. Ahlgren for providing nitrate concentration data. We also thank R. Jones, S. Hietanen and H. Jäntti for helpful comments on our manuscript. Furthermore, we thank the 3 anonymous reviewers for their valuable and constructive comments.

\section{LITERATURE CITED}

Ahlgren I, Sörensson F, Waara T, Vrede K (1994) Nitrogen budgets in relation to microbial transformations in lakes. Ambio 23:367-377

Altschul SF, Madden TL, Schäffer AA, Zhang J, Zhang Z, Miller W, Lipman DJ (1997) Gapped BLAST and PSIBLAST: a new generation of protein database search programs. Nucleic Acids Res 25:3389-3402

Anderson MJ (2001) A new method for non-parametric multivariate analysis of variance. Austral Ecol 26:32-46

Boyle SA, Rich JJ, Bottomley PJ, Cromack K, Myrold DD (2006) Reciprocal transfer effects on denitrifying community composition and activity at forest and meadow sites in the Cascade Mountains of Oregon. Soil Biol Biochem 38: 870-878

Braker G, Ayala-del-Rio HL, Devol AH, Fesefeldt A, Tiedje JM (2001) Community structure of denitrifiers, Bacteria, and Archaea along redox gradients in Pacific northwest marine sediments by terminal restriction fragment length polymorphism analysis of amplified nitrite reductase (nirS) and 16S rRNA genes. Appl Environ Microbiol 67: 1893-1901

Bryant LD, Lorrai C, McGinnis DF, Brand A, Wüest A, Little JC (2010) Variable sediment oxygen uptake in response to dynamic forcing. Limnol Oceanogr 55:950-964

$>$ Cao Y, Green PG, Holden PA (2008) Microbial community composition and denitrifying enzyme activities in salt marsh sediments. Appl Environ Microbiol 74:7585-7595

Christensen PB, Sørensen J (1986) Temporal variation of denitrification activity in plant-covered, littoral sediment from Lake Hampen, Denmark. Appl Environ Microbiol 51: $1174-1179$

> Cowan JLW, Pennock JR, Boynton WR (1996) Seasonal and interannual patterns of sediment-water nutrient and oxygen fluxes in Mobile Bay, Alabama (USA): regulating factors and ecological significance. Mar Ecol Prog Ser 141: 229-245

Dale OR, Tobias CR, Song B (2009) Biogeographical distribution of diverse anaerobic ammonium oxidizing (anammox) bacteria in Cape Fear river estuary. Environ Microbiol 11: 1194-1207

> Dalsgaard T, Thamdrup B, Canfield DE (2005) Anaerobic ammonium oxidation (anammox) in the marine environment. Res Microbiol 156:457-464

Dandie CE, Burton DL, Zebarth BJ, Henderson SL, Trevors JT, Goyer C (2008) Changes in bacterial denitrifier community abundance over time in an agricultural field and their relationship with denitrification activity. Appl Environ Microbiol 74:5997-6005

> De Medina HL, Marín JC, Gutiérrez E, Morales J (2003) Nitrogen mobility at the sediment-water interface of Lake Maracaibo, Venezuela. Water Air Soil Pollut 145:341-357

> Desnues C, Michotey VD, Wieland A, Zhizang C, Fourçans A, Duran R, Bonin PC (2007) Seasonal and diel distribu- tions of denitrifying and bacterial communities in a hypersaline microbial mat (Camargue, France). Water Res 41:3407-3419

- Enwall K, Hallin S (2009) Comparison of T-RFLP and DGGE techniques to assess denitrifier community composition in soil. Lett Appl Microbiol 48:145-148

- Enwall K, Philippot L, Hallin S (2005) Activity and composition of the denitrifying bacterial community respond differently to long-term fertilization. Appl Environ Microbiol 71:8335-8343

> Fortunato CS, Carlini DB, Ewers E, Bushaw-Newton KL (2009) Nitrifier and denitrifier molecular operational taxonomic unit compositions from sites of a freshwater estuary of Chesapeake Bay. Can J Microbiol 55:333-346

Griffiths RI, Whiteley AS, O'Donnell AG, Bailey MJ (2000) Rapid method for coextraction of DNA and RNA from natural environments for analysis of ribosomal DNA- and rRNA-based microbial community composition. Appl Environ Microbiol 66:5488-5491

> Groffman PM, Altabet MA, Böhlke JK, Butterbach-Bahl K and others (2006) Methods for measuring denitrification: diverse approaches to a difficult problem. Ecol Appl 16: 2091-2122

Hallin S, Lindgren PE (1999) PCR detection of genes encoding nitrite reductase in denitrifying bacteria. Appl Environ Microbiol 65:1652-1657

Hallin S, Throbäck IN, Dicksved J, Pell M (2006) Metabolic profiles and genetic diversity of denitrifying communities in activated sludge after addition of methanol or ethanol. Appl Environ Microbiol 72:5445-5452

Hamersley MR, Woebken D, Boehrer B, Schultze M, Lavik G, Kuypers MMM (2009) Water column anammox and denitrification in a temperate permanently stratified lake (Lake Rassnitzer, Germany). Syst Appl Microbiol 32:571-582

Harrison JA, Maranger RJ, Alexander RB, Giblin AE and others (2009) The regional and global significance of nitrogen removal in lakes and reservoirs. Biogeochemistry 93: $143-157$

> Hasegawa T, Okino T (2004) Seasonal variation of denitrification rate in Lake Suwa sediment. Limnology 5:33-39

> Hietanen S (2007) Anaerobic ammonium oxidation (anammox) in sediments of the Gulf of Finland. Aquat Microb Ecol 48:197-205

Hietanen S, Kuparinen J (2008) Seasonal and short-term variation in denitrification and anammox at a coastal station on the Gulf of Finland, Baltic Sea. Hydrobiologia 596:67-77

Hobbs WO, Lalonde SV, Vinebrooke RD, Konhauser KO, Weidman RP, Graham MD, Wolfe AP (2010) Algal-silica cycling and pigment diagenesis in recent alpine lake sediments: mechanisms and paleoecological implications. J Paleolimnol 44:613-628

- Hochberg Y (1988) A sharper Bonferroni procedure for multiple tests of significance. Biometrika 75:800-802

Jäntti H (2007) The spatial and temporal variation of nitrogen fixation in aquatic environments. MSc Thesis, University of Jyväskylä, Jyväskylä

> Junier P, Kim O, Witzel K, Imhoff JF, Hadas O (2008) Habitat partitioning of denitrifying bacterial communities carrying nirS or nirK genes in the stratified water column of Lake Kinneret, Israel. Aquat Microb Ecol 51:129-140

> Kim OS, Imhoff JF, Witzell KP, Junier P (2011) Distribution of denitrifying bacterial communities in the stratified water column and sediment-water interface in two freshwater lakes and the Baltic Sea. Aquat Ecol 45:99-112

Koop-Jakobsen K, Giblin AE (2009) Anammox in tidal marsh sediments: the role of salinity, nitrogen loading, and marsh vegetation. Estuaries Coasts 32:238-245 
Liu WT, Marsh TL, Cheng H, Forney LJ (1997) Characterization of microbial diversity by determining terminal restriction fragment length polymorphisms of genes encoding 16S rRNA. Appl Environ Microbiol 63:4516-4522

Liu XD, Tiquia SM, Holguin G, Wu LY and others (2003) Molecular diversity of denitrifying genes in continental margin sediments within the oxygen-deficient zone off the Pacific coast of Mexico. Appl Environ Microbiol 69: 3549-3560

Maerki M, Müller B, Dinkel C, Wehrli B (2009) Mineralization pathways in lake sediments with different oxygen and organic carbon supply. Limnol Oceanogr 54:428-438

Magalhães C, Bano N, Wiebe WJ, Bordalo AA, Hollibaugh JT (2008) Dynamics of nitrous oxide reductase genes (nosZ) in intertidal rocky biofilms and sediments of the Douro river estuary (Portugal), and their relation to N-biogeochemistry. Microb Ecol 55:259-269

> McArdle BH, Anderson MJ (2001) Fitting multivariate models to community data: a comment on distance-based redundancy analysis. Ecology 82:290-297

- McCarthy MJ, Gardner WS, Lavrentyev PJ, Moats KM, Jochem FJ, Klarer DM (2007) Effects of hydrological flow regime on sediment-water interface and water column nitrogen dynamics in a Great Lakes coastal wetland (Old Woman Creek, Lake Erie). J Gt Lakes Res 33:219-231

Mengis M, Gachter R, Wehrli B, Bernasconi S (1997) Nitrogen elimination in two deep eutrophic lakes. Limnol Oceanogr 42:1530-1543

Müller B, Maerki M, Schmid M, Vologina EG, Wehrli B, Wüest A, Sturm M (2005) Internal carbon and nutrient cycling in Lake Baikal: sedimentation, upwelling, and early diagenesis. Global Planet Change 46:101-124

Murphy J, Riley JP (1962) A modified single solution method for determination of phosphate in natural waters. Anal Chim Acta 27:31-36

Muyzer G, Dewaal EC, Uitterlinden AG (1993) Profiling of complex microbial populations by denaturing gradient gel electrophoresis analysis of polymerase chain reactionamplified genes coding for 16S ribosomal-RNA. Appl Environ Microbiol 59:695-700

Nielsen LP (1992) Denitrification in sediment determined from nitrogen isotope pairing. FEMS Microbiol Lett 86: 357-362

> Nizzoli D, Carraro E, Nigro V, Viaroli P (2010) Effect of organic enrichment and thermal regime on denitrification and dissimilatory nitrate reduction to ammonium (DNRA) in hypolimnetic sediments of two lowland lakes. Water Res 44:2715-2724

Nogales B, Timmis KN, Nedwell DB, Osborn AM (2002) Detection and diversity of expressed denitrification genes in estuarine sediments after reverse transcription-PCR amplification from mRNA. Appl Environ Microbiol 68:5017-5025

> Nõges P, Järvet A, Tuvikene L, Nõges T (1998) The budgets of nitrogen and phosphorus in shallow eutrophic Lake Võrtsjärv (Estonia). Hydrobiologia 363:219-227

O'Connor BL, Hondzo M, Dopraca D, LaPara TM, Finlay JC, Brezonik PL (2006) Quantity-activity relationship of denitrifying bacteria and environmental scaling in streams of a forested watershed. J Geophys Res 111:G04014

Ojala A, Bellido JL, Tulonen T, Kankaala P, Huotari J (2011) Carbon gas fluxes from a brown water and a clear-water lake in the boreal zone during a summer with extreme rain events. Limnol Oceanogr 56:61-76

Perryman SE, Rees GN, Walsh CJ (2008) Analysis of denitrifying communities in streams from an urban and non-urban catchment. Aquat Ecol 42:95-101

Piña-Ochoa E, Álvarez-Cobelas M (2006) Denitrification in aquatic environments: a cross-system analysis. Biogeochemistry 81:111-130

Prosser JI (2010) Replicate or lie. Environ Microbiol 12: $1806-1810$

Quinn G, Keough M (2002) Experimental design and data analysis for biologists. Cambridge University Press

> Revsbech NP, Jacobsen JP, Nielsen LP (2005) Nitrogen transformations in microenvironments of river beds and riparian zones. Ecol Eng 24:447-455

Rich JJ, Myrold DD (2004) Community composition and activities of denitrifying bacteria from adjacent agricultural soil, riparian soil, and creek sediment in Oregon, USA. Soil Biol Biochem 36:1431-1441

Rich JJ, Heichen RS, Bottomley PJ, Cromack K, Myrold DD (2003) Community composition and functioning of denitrifying bacteria from adjacent meadow and forest soils. Appl Environ Microbiol 69:5974-5982

Risgaard-Petersen N, Rysgaard S, Nielsen LP, Revspech NP (1994) Diurnal variation of denitrification and nitrification in sediments colonized by benthic microphytes. Limnol Oceanogr 39:573-579

Risgaard-Petersen N, Skarup S, Nielsen LP (1999) Denitrification in a soft bottom lake: evaluation of laboratory incubations. Aquat Microb Ecol 17:279-287

> Rissanen AJ, Kurhela E, Aho T, Oittinen T, Tiirola M (2010) Storage of environmental samples for guaranteeing nucleic acid yields for molecular microbiological studies. Appl Microbiol Biotechnol 88:977-984

Rösch C, Bothe H (2005) Improved assessment of denitrifying, $\mathrm{N}_{2}$-fixing, and total-community bacteria by terminal restriction fragment length polymorphism analysis using multiple restriction enzymes. Appl Environ Microbiol 71: 2026-2035

Rysgaard S, Risgaard-Petersen N, Sloth NP, Jensen K, Nielsen LP (1994) Oxygen regulation of nitrification and denitrification in sediments. Limnol Oceanogr 39:1643-1652

Rysgaard S, Christensen PB, Nielsen LP (1995) Seasonal variation in nitrification and denitrification in estuarine sediment colonized by benthic microalgae and bioturbating infauna. Mar Ecol Prog Ser 126:111-121

Saunders DL, Kalff J (2001a) Nitrogen retention in wetlands, lakes and rivers. Hydrobiologia 443:205-212

> Saunders DL, Kalff J (2001b) Denitrification rates in the sediments of Lake Memphremagog, Canada-USA. Water Res 35:1897-1904

- Scala DJ, Kerkhof LJ (2000) Horizontal heterogeneity of denitrifying bacterial communities in marine sediments by terminal restriction fragment length polymorphism analysis. Appl Environ Microbiol 66:1980-1986

Schernewski G (2003) Nutrient budgets, dynamics and storm effects in a eutrophic, stratified baltic lake. Acta Hydrochim Hydrobiol 31:152-161

Schubert CJ, Durisch-Kaiser E, Wehrli B, Thamdrup B, Lam P, Kuypers MMM (2006) Anaerobic ammonium oxidation in a tropical freshwater system (Lake Tanganyika). Environ Microbiol 8:1857-1863

- Seitzinger SP (1988) Denitrification in freshwater and coastal marine ecosystems: ecological and geochemical significance. Limnol Oceanogr 33:702-724

Seitzinger SP, Kroeze C, Bouwman AF, Caraco N, Dentener F, Styles RV (2002) Global patterns of dissolved inorganic and particulate nitrogen inputs to coastal systems: recent conditions and future projections. Estuaries 25:640-655

Silvennoinen H, Hietanen S, Liikanen A, Stange CF, Russow R, Kuparinen J, Martikainen PJ (2007) Denitrification in the river estuaries of the northern Baltic Sea. Ambio 36: $134-140$ 
Silvennoinen H, Liikanen A, Torssonen J, Stange CF, Martikainen PJ (2008) Denitrification and nitrous oxide effluxes in boreal, eutrophic river sediments under increasing nitrate load: a laboratory microcosm study. Biogeochemistry 91:105-116

Simola H, Arvola L (2005) Lakes of Northern Europe. In: O'Sullivan PE, Reynolds CS (eds) The lakes handbook, Vol 2: lake restoration and rehabilitation. Blackwell Science, Oxford

Smith CJ, Nedwell DB, Dong LF, Osborn AM (2007) Diversity and abundance of nitrate reductase genes (narG and napA), nitrite reductase genes (nirS and nrfA), and their transcripts in estuarine sediments. Appl Environ Microbiol 73:3612-3622

Sollie S, Verhoeven JTA (2008) Nutrient cycling and retention along a littoral gradient in a Dutch shallow lake in relation to water level regime. Water Air Soil Pollut 193:107-121

Steingruber SM, Friedrich J, Gächter R, Wehrli B (2001) Measurement of denitrification in sediments with the ${ }^{15} \mathrm{~N}$ isotope pairing technique. Appl Environ Microbiol 67: 3771-3778

Svensson JM (1998) Emission of $\mathrm{N}_{2} \mathrm{O}$, nitrification and denitrification in a eutrophic lake sediment bioturbated by Chironomus plumosus. Aquat Microb Ecol 14:289-299

Svensson JM, Enrich-Prast A, Leonardson L (2001) Nitrification and denitrification in a eutrophic lake sediment bioturbated by oligochaetes. Aquat Microb Ecol 23:177-186

Throbäck IN, Enwall K, Jarvis A, Hallin S (2004) Reassessing PCR primers targeting nirS, nirK and nosZ genes for community surveys of denitrifying bacteria with DGGE. FEMS Microbiol Ecol 49:401-417
Tiquia SM, Masson SA, Devol A (2006) Vertical distribution of nitrite reductase genes (nirS) in continental margin sediments of the Gulf of Mexico. FEMS Microbiol Ecol 58: 464-475

- Tuominen L, Heinänen A, Kuparinen J, Nielsen LP (1998) Spatial and temporal variability of denitrification in the sediments of the northern Baltic Proper. Mar Ecol Prog Ser 172:13-24

> Wallenstein MD, Myrold DD, Firestone M, Voytek M (2006) Environmental controls on denitrifying communities and denitrification rates: Insights from molecular methods. Ecol Appl 16:2143-2152

> Wertz S, Dandie CE, Goyer C, Trevors JT, Patten CL (2009) Diversity of nirK denitrifying genes and transcripts in an agricultural soil. Appl Environ Microbiol 75:7365-7377

- Wolsing M, Priemé A (2004) Observation of high seasonal variation in community structure of denitrifying bacteria in arable soil receiving artificial fertilizer and cattle manure by determining T-RFLP of nir gene fragments. FEMS Microbiol Ecol 48:261-271

Wood ED, Armstrong FA, Richards FA (1967) Determination of nitrate in sea water by cadmium-copper reduction to nitrite. J Mar Biol Assoc UK 47:23-31

Wu L, Kellogg L, Devol AH, Tiedje JM, Zhou J (2008) Microarray-based characterization of microbial community functional structure and heterogeneity in marine sediments from the gulf of Mexico. Appl Environ Microbiol 74:4516-4529

- Zumft WG (1997) Cell biology and molecular basis of denitrification. Microbiol Mol Biol Rev 61:533-616 
Appendix 1.
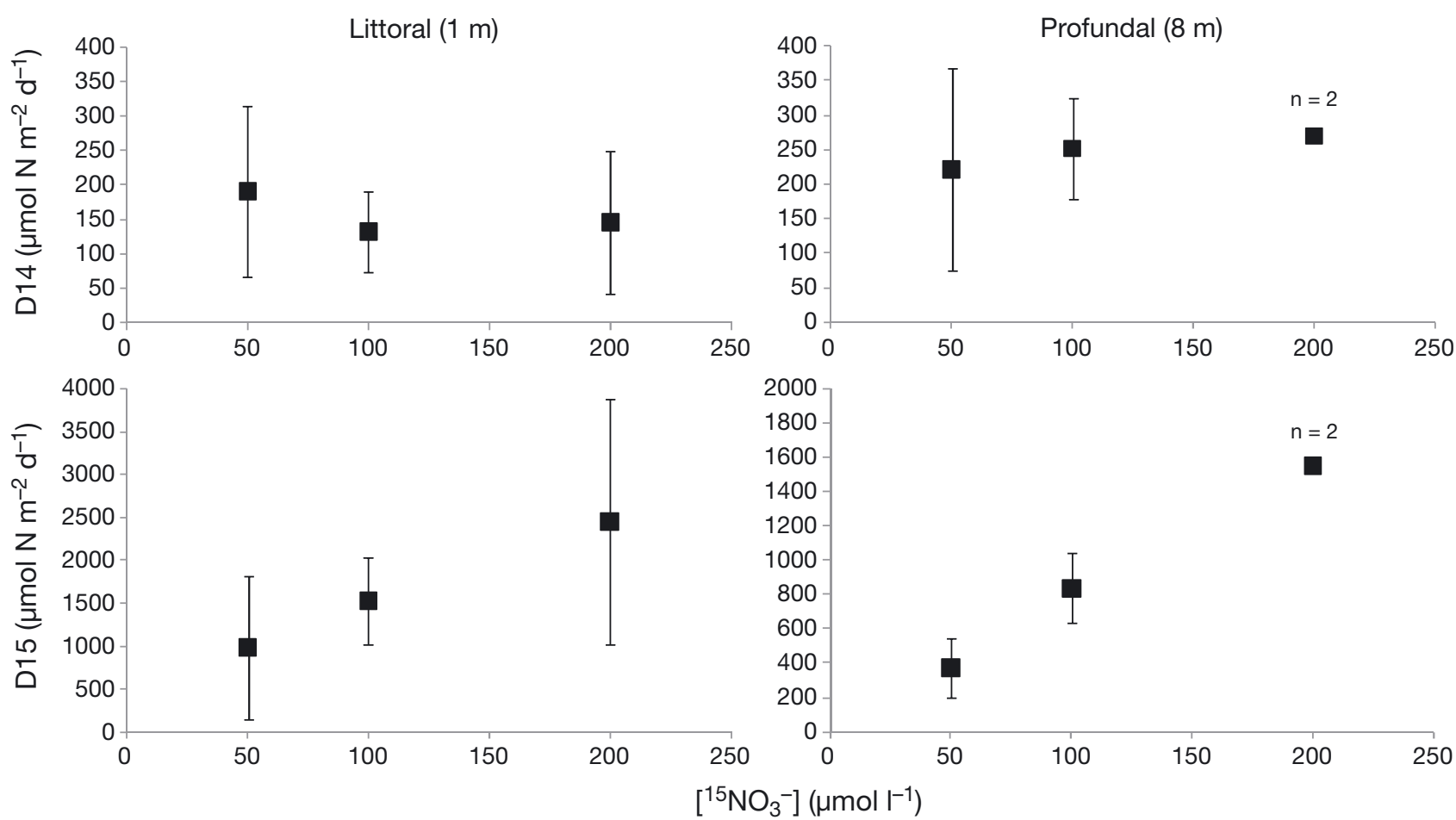

Fig. A1. D14 (denitrification of the natural ${ }^{14} \mathrm{NO}_{3}{ }^{-}$) and D15 (denitrification of the added ${ }^{15} \mathrm{NO}_{3}{ }^{-}$) of ${ }^{15} \mathrm{NO}_{3}{ }^{-}$concentration tests in October 2006. Data are mean \pm SD. $n=3$, unless otherwise indicated

Table A1. Correlations (Spearman's rho) $(\mathrm{p}<0.05)$ of square-root-transformed relative percentage abundances of different nirK operational taxonomic units (OTUs) with environmental factors (see Table 1) and with the denitrification rate of natural ${ }^{14} \mathrm{NO}_{3}{ }^{-}$(D14). $\mathrm{n}=35$, except for analyses of $\mathrm{pH}$, where $\mathrm{n}=32$

\begin{tabular}{|ccccccccccc|}
\hline & LOI & Porosity & $\begin{array}{c}\mathrm{O}_{2} \\
\text { sat. }(\%)\end{array}$ & {$\left[\mathrm{NH}_{4}{ }^{+}\right]$} & {$\left[\mathrm{NO}_{3}{ }^{-}\right]$} & $\mathrm{pH}$ & {$\left[\mathrm{PO}_{4}{ }^{-}\right]$} & {$\left[\mathrm{O}_{2}\right]$} & $T$ & D14 \\
& & & & & & & & & \\
\hline OTU1 & - & -0.36 & - & - & - & - & - & - & - & - \\
OTU2 & - & - & - & 0.45 & - & - & - & -0.37 & - & - \\
OTU3 & - & - & - & - & - & 0.38 & - & - & - & - \\
OTU4 & 0.77 & 0.57 & -0.65 & 0.42 & 0.39 & -0.62 & - & - & - & - \\
OTU5 & 0.88 & 0.67 & -0.45 & - & 0.52 & -0.54 & 0.34 & - & - & - \\
OTU7 & - & -0.40 & - & - & - & - & - & - & - & - \\
OTU8 & - & - & -0.46 & - & - & - & - & - & - & - \\
OTU9 & - & -0.34 & - & - & - & - & - & - & - & - \\
OTU10 & 0.65 & 0.73 & -0.50 & - & 0.42 & -0.37 & - & - & - & 0.46 \\
OTU11 & - & 0.39 & - & -0.50 & - & - & - & - & - & - \\
OTU12 & -0.47 & -0.35 & 0.42 & - & -0.38 & 0.46 & - & - & 0.35 & - \\
OTU13 & 0.63 & 0.69 & - & - & - & - & 0.37 & - & - & - \\
OTU15 & -0.80 & -0.81 & 0.49 & - & -0.36 & - & -0.34 & - & - & - \\
OTU16 & 0.53 & - & -0.70 & 0.38 & - & -0.45 & - & -0.39 & - & - \\
OTU17 & 0.42 & 0.48 & - & - & - & - & - & - & - & - \\
OTU18 & 0.34 & - & -0.67 & - & 0.36 & -0.51 & - & - & -0.37 & - \\
OTU19 & -0.37 & -0.40 & - & -0.36 & - & - & - & - & - & - \\
OTU22 & - & - & - & - & -0.38 & - & -0.37 & - & 0.35 & - \\
OTU24 & -0.50 & -0.39 & 0.34 & -0.41 & -0.39 & 0.53 & - & - & - & - \\
OTU25 & -0.79 & -0.80 & 0.45 & - & - & - & - & - & - & - \\
OTU26 & -0.78 & -0.84 & 0.48 & - & -0.36 & - & - & - & - & - \\
\hline
\end{tabular}

Editorial responsibility: Tom Battin, Vienna, Austria
Submitted: August 9, 2010; Accepted: March 17, 2011 Proofs received from author(s): June 1, 2011 